\title{
Low Protein Diet Alters Urea Transport and Cell Structure in Rat Initial Inner Medullary Collecting Duct
}

\author{
Taisuke Isozaki, ${ }^{\star}$ Jill W. Verlander, ${ }^{\star}$ and Jeff M. Sands* \\ Renal Divisions, Departments of Medicine, *Emory University School of Medicine, Atlanta, Georgia 30322; \\ and $^{\ddagger}$ The University of Florida, Gainesville, Florida 32610
}

\begin{abstract}
Low protein diets reverse the urea concentration gradient in the renal inner medulla. To investigate the mechanism(s) for this change, we studied urea transport and cell ultrastructure in initial and terminal inner medullary collecting ducts (IMCD) from rats fed $18 \%$ protein or an isocaloric, $8 \%$ protein diet for 4 wk. Serum urea, aldosterone, and albumin were significantly lower in rats fed $8 \%$ protein, but total protein and potassium were unchanged. Vasopressin stimulated passive urea permeability $\left(P_{\text {uree }}\right)$ threefold $(P<0.05)$ in initial IMCDs from rats fed $8 \%$ protein, but not from rats fed $18 \%$ protein. Luminal phloretin reversibly inhibited vasopressin-stimulated $\mathbf{P}_{\text {urea }}$. However, in terminal IMCDs from rats fed either diet, vasopressin stimulated $\mathbf{P}_{\text {urea. }}$ Net transepithelial urea flux (measured with identical perfusate and bath solutions) was found only in initial IMCDs from rats fed $8 \%$ protein. Reducing the temperature reversibly inhibited it, but phloretin did not. Electron microscopy of initial IMCD principal cells from rats fed 8\% protein showed expanded Golgi bodies and prominent autophagic vacuoles, and morphometric analysis demonstrated a marked increase in the surface density and boundary length of the basolateral plasma membrane. These ultrastructural changes were not observed in the terminal IMCD. Thus, $8 \%$ dietary protein causes two new urea transport processes to appear in initial but not terminal IMCDs. This is the first demonstration that "active" urea transport can be induced in a mammalian collecting duct segment. (J. Clin. Invest. 1993. 92:2448-2457.) Key Words: urea • low protein diet • vasopressin $\bullet$ concentrating mechanism • principal cell
\end{abstract}

\section{Introduction}

In rats fed an $18-24 \%$ protein diet, the inner medullary urea concentration increases with depth, reaching a maximum at the papillary tip (1-3). The urinary urea concentration exceeds

Portions of this manuscript were presented at the 76th Annual Meeting of the Federation of American Societies for Experimental Biology, Anaheim, CA, 5-9 April 1992 and the 25th Annual Meeting of the American Society of Nephrology, Baltimore, MD, 15-18 November 1992; and published in abstract form (1992. Fed. Am. Soc. Exp. Biol. J. 6:A957; and 1992. J. Am. Soc. Nephrol. 3:794-795).

Address correspondence and reprint requests to Dr. J. M. Sands, Emory University School of Medicine, Renal Division, 1364 Clifton Road, NE, Atlanta, GA 30322.

Received for publication 1 February 1993 and in revised form 1 June 1993.

J. Clin. Invest.

(C) The American Society for Clinical Investigation, Inc. $0021-9738 / 93 / 11 / 2448 / 10 \quad \$ 2.00$

Volume 92, November 1993, 2448-2457 the maximal urea concentration in the papilla, consistent with passive urea reabsorption (1-3). Low protein diets change inner medullary urea handling in the rat (1-12), sheep (13-17), camel (18), and man (19). In rats fed a low protein diet, fractional excretion of urea is significantly reduced compared to rats fed normal or high protein diets, consistent with stimulation of urea reabsorption by protein restriction $(1,5,8,10,12)$. Moreover, the normal inner medullary urea concentration profile is reversed by restricting dietary protein (1-3). In rats fed a low protein diet, the maximum inner medullary urea concentration is not found near the papillary tip, but instead, is near the base of the inner medulla (1-3), corresponding to the location of the initial inner medullary collecting duct (IMCD) ${ }^{1}$ $(20,21)$. Taken together, these data suggest that a low protein diet might induce active urea transport in the $\operatorname{IMCD}(1-3,22)$.

Indeed, results from micropuncture studies in rats fed a low protein diet suggest there is "active" urea reabsorption from the collecting duct $(4,6,7,9,11,23,24)$. Unfortunately, use of micropuncture to establish that a low protein diet can induce active transport of urea is limited by the inability to measure the urea gradient across the collecting duct in vivo. Consequently, this technique cannot definitively prove active urea reabsorption.

To define changes in urea transport induced by a low protein diet, we perfused initial IMCD $\left(\mathrm{IMCD}_{1}\right)$ and terminal IMCD $\left(\mathrm{IMCD}_{2}\right)$ IMCDs microdissected from rats maintained on low $(8 \%)$ protein diets and on standard $(18 \%)$ protein diets. We also used transmission and scanning electron microscopy to determine whether dietary protein restriction induces ultrastructural changes in initial or terminal IMCDs.

\section{Methods}

Animals. Pathogen-free male Sprague-Dawley rats (Harlan SpragueDawley, Indianapolis, IN) were kept in filter-top cages with autoclaved bedding and received free access to water and autoclaved rat chow. The standard diet contained $18 \%$ protein (NIH-31 diet; Ziegler Brothers Inc., Gardner, PA). The low protein diet contained $8 \%$ protein, was isocaloric with the standard diet, and was supplemented with methionine, lysine, calcium, and phosphate to match the levels in the standard diet (NIH-31LP diet; Ziegler Brothers Inc.). This low protein diet has been shown to prevent malnutrition in rats $(1,5)$.

After feeding rats one of the two diets for $4 \mathrm{wk}$, rats were placed in individual metabolic cages for a 24-h urine collection and food consumption was measured. Blood was collected on the day of tubule perfusion. Serum concentrations of creatinine, urea nitrogen, albumin, total protein, and potassium were measured by the Emory University Veterinary Services Laboratory. Serum aldosterone was measured by the Emory Nephrology Radioimmunoassay Laboratory.

Tissue preparation for tubule microperfusion. $20 \mathrm{~min}$ before each experiment, furosemide $(5 \mathrm{mg})$ was administered intraperitoneally

1. Abbreviations used in this paper: IMCD, inner medullary collecting duct; IMCD 1 , initial IMCD; IMCD 2 , terminal IMCD. 
(25). The kidneys were placed into chilled $\left(17^{\circ} \mathrm{C}\right)$, isotonic, dissecting solution to isolate initial or terminal IMCDs as described previously (21). The dissecting solution was gassed with $95 \% \mathrm{O}_{2}$ and $5 \% \mathrm{CO}_{2}$ and contained (in mM): $118 \mathrm{NaCl}, 25 \mathrm{NaHCO}_{3}, 2 \mathrm{CaCl}_{2}, 2.5 \mathrm{~K}_{2} \mathrm{HPO}_{4}, 1.2$ $\mathrm{MgSO}_{4}, 5.5$ glucose, and 4 creatinine. Initial IMCDs were dissected between the inner-outer medullary border (defined by the disappearance of thick ascending limbs) and the first bifurcation of collecting ducts within the inner medulla $(21,25)$. Terminal IMCDs were dissected between 50 and $70 \%$ of the distance from the inner-outer medullary junction and the papillary tip $(21,25)$, which corresponds to the segment designated $\mathrm{IMCD}_{2}$ in the morphologic studies of Clapp et al. $(26,27)$. The tubules were perfused after transfer into a bath that was exchanged continuously at a rate of $1 \mathrm{ml} / \mathrm{min}$ and was bubbled with $95 \% \mathrm{O}_{2} / 5 \% \mathrm{CO}_{2}$ gas $(21,25)$. Solution osmolality was measured by freezing point depression (Micro Osmette, model 5004; Precision Systems, Inc., Natick, MA).

Urea measurement. The urea concentration in perfusate, bath, and collected fluid was measured using a continuous-flow ultramicro-fluorometer (21). Urea flux $\left(J_{\text {urea }}\right)$ was calculated as: $J_{\text {urea }}=C_{0} \cdot V_{0}-C_{1} \cdot V_{1}$, where $C_{0}$ is the urea concentration in the perfusate, $C_{1}$ the urea concentration in the collected fluid, $V_{0}$ is the perfusion rate per unit length of tubule, and $V_{1}$ is the collection rate per unit length of tubule. To study net transport (described below), $V_{0}$ was assumed to be equal to $V_{1}$, as there was no vasopressin in the bath, no osmotic gradient across the tubule, and hence, no driving force for water reabsorption.

The urea permeability $\left(P_{\text {urea }}\right)$ was calculated from $J_{\text {urea }}$ as: $P_{\text {urea }}$ $=\mathrm{J}_{\text {urea }} /\left(\pi \cdot \mathrm{ID} \cdot \delta \mathrm{C}_{\mathrm{lm}}\right)$, where $\delta \mathrm{C}_{\mathrm{lm}}$ is the log-mean urea concentration difference along the tubule and ID is the tubule inner diameter as measured with an eyepiece micrometer.

Volume flux measurement. Creatinine concentration in perfusate, bath, and collected fluid was measured using a continuous-flow ultramicro-colorimeter and used to measure volume flux $(21,28,29)$. The perfusion rate $\left(\mathrm{V}_{0}\right)$ was calculated as: $\mathrm{V}_{0}=\mathrm{V}_{1}\left(\mathrm{Cr}_{\mathrm{l}} / \mathrm{Cr}_{0}\right)$, where $\mathrm{Cr}_{\mathrm{o}}$ is the creatinine concentration in the perfusate, $\mathrm{Cr}_{1}$ the creatinine concentration in the collected fluid, and $V_{0}$ and $V_{1}$ are as defined above. Fluid flux $\left(\mathrm{J}_{\mathrm{v}}\right)$ was calculated as: $\mathrm{J}_{\mathrm{v}}=\mathrm{V}_{\mathrm{o}}-\mathrm{V}_{\mathrm{l}}$.

Passive urea permeability protocol. To determine the passive urea permeability in initial or terminal IMCDs from rats fed $18 \%$ or $8 \%$ protein, $5-\mathrm{mM}$ urea was added to the bath solution and $5 \mathrm{mM}$ raffinose was added to the perfusate to create a 5-mM bath-to-lumen urea gradient without any osmotic gradient. After three to four control collections, $10 \mathrm{nM}$ vasopressin (Sigma Chemical Co., St. Louis, MO) was added to the bath and an additional three to four collections obtained. Other tubules were studied but vasopressin was not added before the second set of collections, followed by a "sham" bath exchange and an additional three to four collections (time control experiments).

Phloretin protocol. Phloretin is an inhibitor of facilitated urea transport in rat terminal IMCDs (30-32). A $250 \mathrm{mM}$ phloretin (Sigma Chemical Co.) stock solution was prepared in absolute ethanol and used to prepare perfusate solutions with a final concentration of 250 $\mu \mathrm{M}$ phloretin and $0.1 \%$ ethanol $(30,32)$. Control collections were obtained with $0.1 \%$ ethanol added to the perfusate $(30,32)$. Vasopressin $(10 \mathrm{nM})$ was added to the bath throughout this experimental protocol. After control measurements, three to four collections were obtained with $250 \mu \mathrm{M}$ phloretin added to the perfusate, followed by an additional three to four collections after phloretin had been washed out.

Net urea transport protocol. To determine whether net urea transport occurred in initial or terminal IMCDs in the absence of vasopressin, tubules were perfused with perfusate and bath solutions that were identical to the dissecting solution (described above), except that $3 \mathrm{mM}$ urea was added to all solutions. Thus, there was no transepithelial urea or osmotic gradient across the perfused tubule and no vasopressin in the bath. We found no difference in the urea concentration of fluid entering and exiting the bath, indicating that the bath flow rate was sufficiently rapid to prevent any evaporative change in bath urea concentration (data not shown). The urea concentration of several collections was measured in each tubule, matched by an equal number of measurements of perfusate and bath urea concentrations.
In calculating urea flux, we assumed that the perfusion and collection rates were equal under our experimental conditions; i.e., no net fluid flux. To test this assumption, we measured the perfusion rate by simultaneously measuring fluid flux $\left(\mathrm{J}_{\mathrm{v}}\right)$ and urea flux $\left(\mathrm{J}_{\text {urea }}\right)$.

Phloretin effect on net urea transport. The effect of phloretin on net urea transport was investigated in the absence of vasopressin. The protocol was otherwise identical to the phloretin protocol described above.

Inhibition of net urea transport by temperature. To examine whether net urea transport is inhibited by decreasing tubule temperature, the bath was continuously exchanged and gassed; however, the tubule was not warmed, but was equilibrated for $40 \mathrm{~min}$ at room temperature $\left(23^{\circ} \mathrm{C}\right)$ before three to four collections were made. Next, the tubule was warmed to $37^{\circ} \mathrm{C}$ and three to four collections were obtained. Finally, the tubule was cooled to room temperature, and an additional three to four collections were obtained.

Electron microscopy. Rats fed 18 or $8 \%$ protein for 4 wk were anesthetized intraperitoneally with sodium pentobarbital and $100 \mathrm{U}$ of heparin were injected into the carotid artery. The kidneys were rinsed by vascular perfusion with $0.1 \mathrm{M}$ sodium cacodylate in PBS (pH 7.4, 530 $\operatorname{mos} \mathrm{M} /$ liter) and then fixed by perfusion with $3 \%$ glutaraldehyde, $4 \%$ polyvinylpyrrolidone in $0.1 \mathrm{M}$ sodium cacodylate, and PBS ( $\mathrm{pH} 7.4$, $890 \mathrm{mosM} / \mathrm{liter})(26,27)$. The kidneys were immersed in the same fixative for $2-4 \mathrm{~h}$ at room temperature, then overnight at $4^{\circ} \mathrm{C}$. Samples from the base of the inner medulla and the proximal portion of the papilla (26) were postfixed for $1 \mathrm{~h}$ in $2 \%$ osmium tetroxide in $0.1 \mathrm{M}$ sodium cacodylate. The tissue was dehydrated in a graded series of ethanols and propylene oxide and embedded in epoxy resin (Pelco Medcast; Ted Pella Inc., Redding, CA).

Sections containing well-fixed collecting duct were selected by observation of $1-\mu \mathrm{m}$ thick sections by light microscopy. Thin sections of selected areas were cut, counterstained with uranyl acetate and lead citrate, and observed using a transmission electron microscope (model 10A; Carl Zeiss, Inc., Thornwood, NY). To ensure unbiased interpretation of any morphologic differences, the photomicrographs were reviewed by Dr. C. Craig Tisher (The University of Florida, Gainesville, FL), who was blinded regarding the protein content of each rat's diet.

For scanning electron microscopy, after perfusion and overnight immersion fixation, 1-2-mm slices of whole kidney were cut in the transverse plane through the papilla. Tissue slices were postfixed for $1 \mathrm{~h}$ in $1 \%$ osmium tetroxide in $0.1 \mathrm{M}$ sodium cacodylate at $4^{\circ} \mathrm{C}$. The tissue was rinsed in $0.1 \mathrm{M}$ sodium cacodylate then dehydrated in a graded series of acetones. The samples were dried by heating to the critical point in $\mathrm{CO}_{2}$, mounted on brass stubs, and sputter-coated with palladium gold. Samples were observed with a scanning electron microscope (model DS 130C; International Scientific Instruments, Inc., Pleasanton, CA).

Morphometric analysis. Five cells in the $\mathrm{IMCD}_{1}$ or $\mathrm{IMCD}_{2}$ from each rat were selected randomly and photographed at a primary magnification of 5,000. Intercalated cells were excluded from the morphometric analysis. Individual photomicrographs or montages of cells were examined at a final magnification of $\sim 19,000$. The exact magnification was calculated using a calibration grid with 2,160 lines per millimeter.

Cell profile area, surface densities, and boundary lengths for the apical and basolateral plasma membrane compartments were determined by point and intersection counting using the Merz curvilinear test grid with a distance of $20 \mathrm{~mm}$ between the points, corresponding to $1.016 \mu \mathrm{m}(d)$. Cell profile area $\left(\mathrm{A}, \mathrm{mm}^{2}\right)$ was estimated in each rat as: $\mathrm{A}$ $=\mathrm{P}\left(d^{2}\right)$, where $\mathrm{P}$ is the number of points over the cell profile, and $d$ is the distance between points.

The surface density $\left(\mathrm{S}_{\mathrm{v}}, \mathrm{mm}^{2} / \mathrm{mm}^{3}\right)$ of the apical and basolateral plasma membranes was calculated as: $S_{v}=2(I / L)$, where $I$ is the number of intersections between the test line and the plasma membrane and $\mathrm{L}$ is the length of the test line, which on Merz grid equals $\mathrm{P}(\pi / 2) d$, where $\mathrm{P}$ represents the number of points over the cell, and $d$ is as defined above. The boundary length $(B, \mu \mathrm{m})$ of the apical and basolateral plasma membrane compartments of each cell was calculated as: $B=\mathrm{I}(d)$, where $\mathrm{I}$ and $d$ are as defined above. 
Statistics. For the perfusion experiments, data from three to four collections were averaged to obtain a single value from each experimental phase in each tubule. For the morphometric studies, point and intersection counts from five cells from each rat were averaged. These figures were entered in the respective equations to determine values for $A, S_{v}$, and $B$, representative of each rat. The data are presented as mean $\pm \mathrm{SE}$, and $n=$ number of rats. To test for statistical significance between two groups, a $t$ test was used. To test for statistical significance between more than two groups, an ANOVA was used, followed by a multiple comparisons, protected $t$ test (33) to determine which groups were significantly different. The criterion for statistical significance was $P<0.05$.

\section{Results}

Nutritional parameters. The rats gained $2-3 \mathrm{~g} / \mathrm{d}$ on the $8 \%$ protein diet vs $5-6 \mathrm{~g} / \mathrm{d}$ on the $18 \%$ protein diet. Blood urea nitrogen and albumin were significantly lower in the rats fed $8 \%$ protein; however, serum creatinine and total protein were unchanged in rats fed either diet (Table I). Serum aldosterone was significantly lower in rats fed $8 \%$ protein $(33.1 \pm 8.3 \mathrm{pg} / \mathrm{ml}$, $n=7)$ than in rats fed $18 \%$ protein $(78.0 \pm 2.4, n=6, P<0.002)$. However, serum potassium was not significantly different between rats fed $18 \%$ protein $(4.3 \pm 0.2, n=5)$ or $8 \%$ protein (5.2 $\pm 0.3, n=5, P=\mathrm{NS})$. Protein intake, urinary urea, and fractional excretion of urea $\left(\mathrm{FE}_{\text {urea }}\right)$ were lower in rats fed the $8 \%$ protein diet.

Passive urea permeability. Initial IMCDs from rats fed $18 \%$ protein had a basal passive urea permeability of $3.5 \pm 0.9 \times 10^{-5}$ $\mathrm{cm} / \mathrm{s}(n=6)$. Vasopressin $(10 \mathrm{nM})$ added to the bath did not change passive urea permeability $\left(2.1 \pm 1.0 \times 10^{-5} \mathrm{~cm} / \mathrm{s}, n\right.$ $=3$ ). Initial IMCDs from rats fed $8 \%$ protein for 4 wk had a basal passive urea permeability of $5.1 \pm 0.7 \times 10^{-5} \mathrm{~cm} / \mathrm{s}(n=10$, $P=$ NS vs $18 \%$ protein). Vasopressin $(10 \mathrm{nM})$ significantly increased passive urea permeability to $15.4 \pm 3.8 \times 10^{-5} \mathrm{~cm} / \mathrm{s}$ (Fig. 1, left panel). There was no change in passive urea permeability during time control experiments (Fig. 1, right panel).

Phloretin reversibly inhibited vasopressin-stimulated passive urea permeability from $18.3 \pm 4.2$ to $5.3 \pm 1.2 \times 10^{-5} \mathrm{~cm} / \mathrm{s}$ ( $n=6, P<0.05$ ), Fig. 2). When phloretin was removed, vasopressin-stimulated passive urea permeability returned to $24.0 \pm 3.4 \times 10^{-5} \mathrm{~cm} / \mathrm{s}$ ( $n=6, P=$ NS vs control, Fig. 2$)$.

Terminal IMCDs from rats fed $18 \%$ protein had a basal passive urea permeability of $17.7 \pm 1.4 \times 10^{-5} \mathrm{~cm} / \mathrm{s}(n=3)$. Vasopressin $(10 \mathrm{nM})$ significantly increased urea permeability to $60.2 \pm 20.8 \times 10^{-5} \mathrm{~cm} / \mathrm{s}(n=3, P<0.05)$. Terminal IMCDs from rats fed $8 \%$ protein for 4 wk had a basal passive urea permeability of $22.0 \pm 4.5 \times 10^{-5} \mathrm{~cm} / \mathrm{s}(n=5, P=\mathrm{NS}$ vs $18 \%$ protein). Vasopressin (10 $\mathrm{nM}$ ) significantly increased urea permeability to $46.5 \pm 2.5 \times 10^{-5} \mathrm{~cm} / \mathrm{s}(n=5, P<0.05$ vs basal

Table I. Blood Chemistry Values

\begin{tabular}{lccrcc}
\hline \multicolumn{1}{c}{ Diet } & $n$ & Creatinine & \multicolumn{1}{c}{ BUN } & Albumin & Total protein \\
\hline & & $m g / d l$ & $m g / d l$ & $g / d l$ & $g / d l$ \\
18\% Protein & 12 & $0.48 \pm 0.02$ & $13.6 \pm 1.2$ & $3.8 \pm 0.1$ & $5.4 \pm 0.2$ \\
8\% Protein & 30 & $0.52 \pm 0.02$ & $9.7 \pm 0.6$ & $3.4 \pm 0.1$ & $5.2 \pm 0.1$ \\
& & $P=$ NS & $P<0.01$ & $P<0.01$ & $P=$ NS
\end{tabular}

All values were measured from plasma. Data presented as mean $\pm \mathrm{SE}$. $P$ values determined by unpaired $t$ test. BUN, blood urea nitrogen.

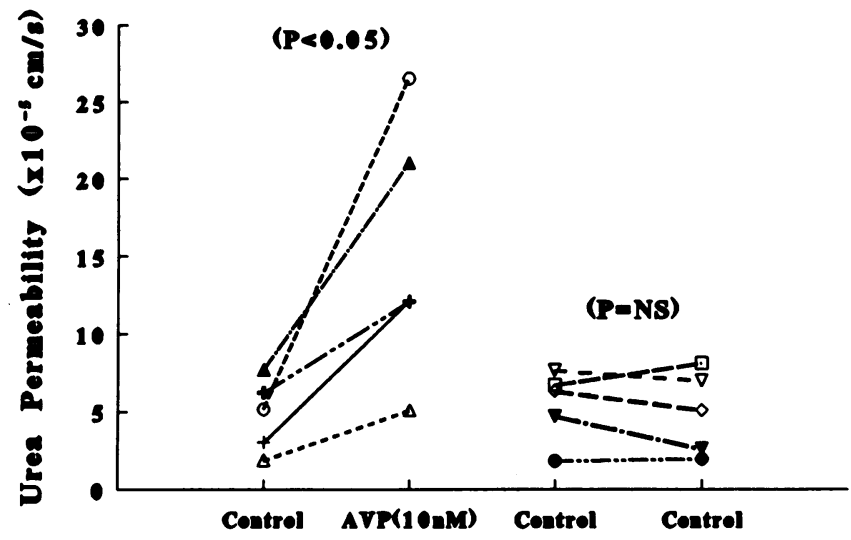

Figure 1. Passive urea permeability was measured in initial IMCDs from rats fed $8 \%$ protein. Lines connect data from individual tubules. Vasopressin $(10 \mathrm{nM})$ significantly increased passive urea permeability (left panel). There was no significant change in passive urea permeability in time control studies (right panel).

urea permeability, $P=$ NS vs $18 \%$ protein with vasopressin, Fig. 3).

Net urea flux. In initial IMCDs from rats fed $8 \%$ protein for $4 \mathrm{wk}$, there was a significant net transepithelial urea flux (4.8 $\pm 0.6 \mathrm{pmol} / \mathrm{mm}$ per $\mathrm{min}, n=13, P<0.002$, Fig. 4) without any net water flux (Table II). In contrast, there was no net urea flux in initial IMCDs from rats fed $18 \%$ protein $(0.5 \pm 0.7 \mathrm{pmol} /$ mm per min, $n=4, P=\mathrm{NS}$, Fig. 4). The net urea flux in initial IMCDs from rats fed $8 \%$ protein was not inhibited by phloretin (control: $3.7 \pm 1.8 \mathrm{pmol} / \mathrm{mm}$ per min, phloretin: $5.5 \pm 1.2 \mathrm{pmol} /$ $\mathrm{mm}$ per min, washout: $6.2 \pm 1.5 \mathrm{pmol} / \mathrm{mm}$ per $\min , n=4, P$ $=$ NS).

In contrast to initial IMCDs, there was no significant net transepithelial urea flux in terminal IMCDs from rats fed $18 \%$ protein $(0.2 \pm 0.3 \mathrm{pmol} / \mathrm{mm}$ per min, $n=4, P=\mathrm{NS}$, Fig. 4$)$ or

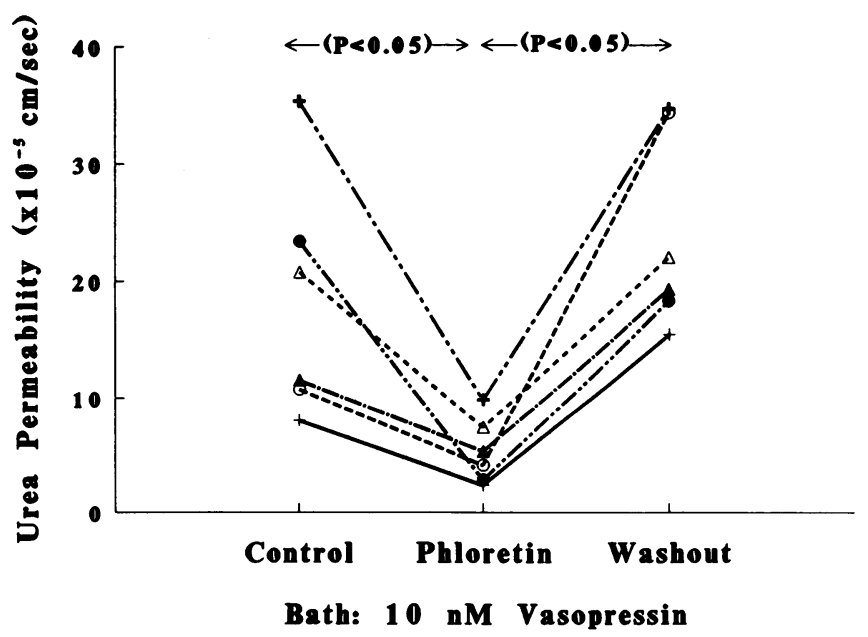

Figure 2. The effect of phloretin ( $0.25 \mathrm{mM}$ added to the lumen) on vasopressin-stimulated, passive urea permeability was measured in initial IMCDs from rats fed $8 \%$ protein. Lines connect data from individual tubules. Phloretin significantly inhibited vasopressin-stimulated passive urea permeability. When phloretin was removed, vasopressin-stimulated passive urea permeability returned to control values. 


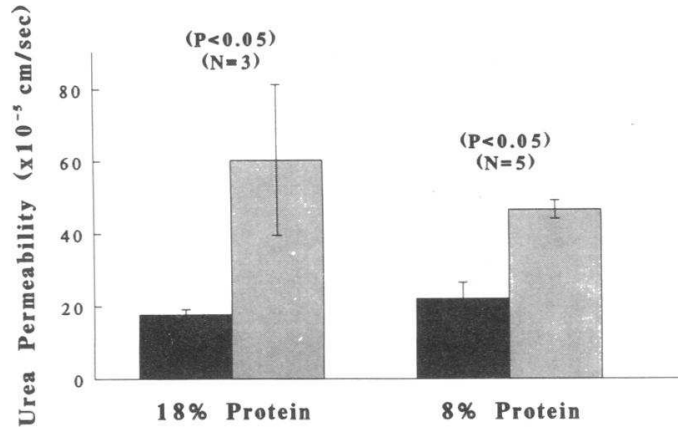

Figure 3. Basal and vasopressin-stimulated passive urea permeabilities were measured in terminal IMCDs from rats fed $18 \%$ protein or $8 \%$ protein for $4 \mathrm{wk}$. Vasopressin $(10 \mathrm{nM})$ significantly increased urea permeability in terminal IMCDs from rats fed either diet. There was no significant difference between basal urea permeabilities or vasopressin-stimulated urea permeabilities between rats fed either diet. $\mathbf{m}$, Basal;, arginine vasopressin (10 nM).

$8 \%$ protein for $4 \mathrm{wk}(0.7 \pm 0.2 \mathrm{pmol} / \mathrm{mm}$ per $\min , n=4$, $P=$ NS, Fig. 4).

To determine whether net transepithelial urea flux was inhibitable by decreasing tubule temperature, initial IMCDs from rats fed $8 \%$ protein were studied at $23^{\circ} \mathrm{C}$ and $37^{\circ} \mathrm{C}$. There was no significant net urea flux at $23^{\circ} \mathrm{C}(1.6 \pm 1.3 \mathrm{pmol} / \mathrm{mm}$ per $\min , n=5, P=$ NS, Fig. 5). Significant net urea flux was present when the tubule was warmed to $37^{\circ} \mathrm{C}(5.6 \pm 1.5 \mathrm{pmol} /$ mm per min, $n=5, P<0.02$, Fig. 5), but disappeared when the tubule was cooled back to $23^{\circ} \mathrm{C}(2.8 \pm 1.6 \mathrm{pmol} / \mathrm{mm}$ per min, $n$ $=5, P=$ NS, Fig. 5).

Electron microscopy. Transmission electron microscopy of initial IMCDs from rats fed $18 \%$ protein revealed ultrastructural features characteristic of principal cells in this segment (27). The cells exhibited sparse, short microprojections of the apical plasma membrane, relatively complex basolateral plasma membrane infoldings, few mitochondria, and a low cuboidal profile (Figs. 6 and 7). Lysosomes were common and typically contained homogeneous material (Fig. 7). Ultrastructural observation of the principal cells in initial IMCDs from rats fed $8 \%$ protein revealed a marked increase in the complexity of the basolateral plasma membrane (Figs. 8-10). Lyso-

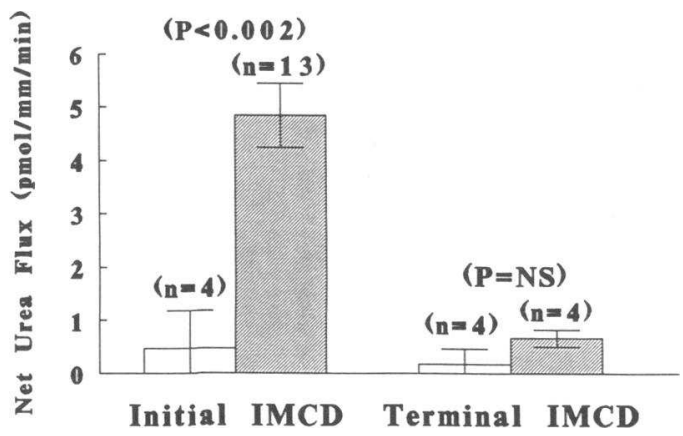

Figure 4. Initial or terminal IMCDs from rats fed $18 \%$ protein $(\square)$ and $8 \%$ protein (ש) were perfused with identical perfusate and bath solutions. There was no significant net urea flux in initial IMCDs from rats fed $18 \%$ protein. However, feeding $8 \%$ protein resulted in significant net urea flux. There was no significant net urea flux in terminal IMCDs from rats fed 18 or $8 \%$ protein.
Table II. Summary of Simultaneous Fluid and Urea Flux Measurements in Initial IMCDs of Rats Fed 8\% Protein for 4 wk

\begin{tabular}{|c|c|c|c|c|c|c|}
\hline $\begin{array}{c}\text { Rat } \\
\text { number }\end{array}$ & $\begin{array}{l}\text { Tubule } \\
\text { length }\end{array}$ & $\begin{array}{l}\text { Collection } \\
\text { rate }\end{array}$ & $\begin{array}{l}\text { Perfusion } \\
\text { Rate }\end{array}$ & $\begin{array}{l}\mathrm{C} / \mathrm{P} \\
\text { creat }\end{array}$ & $\begin{array}{l}\text { Fluid flux } \\
\left(\mathrm{J}_{\mathrm{v}}\right)\end{array}$ & $\begin{array}{c}\text { Urea flux } \\
\left(\mathrm{J}_{\text {urea }}\right)\end{array}$ \\
\hline & $m m$ & \multicolumn{2}{|c|}{$\mathrm{nl} / \mathrm{min}$} & & $\mathrm{nl} / \mathrm{mm}$ per min & $\mathrm{pmol} / \mathrm{mm}$ per min \\
\hline 1 & 0.55 & 9.63 & 9.57 & 0.99 & -0.12 & 5.89 \\
\hline 2 & 0.48 & 10.27 & 10.28 & 1.00 & 0.02 & 8.75 \\
\hline 3 & 0.41 & 10.15 & 10.25 & 1.01 & 0.25 & 5.97 \\
\hline Mean & 0.48 & 10.02 & 10.03 & 1.00 & 0.05 & 6.87 \\
\hline SE & \pm 0.04 & \pm 0.20 & \pm 0.23 & \pm 0.01 & \pm 0.11 & \pm 0.94 \\
\hline$P$ & & & & & NS & $<0.02$ \\
\hline
\end{tabular}

$\mathrm{C} / \mathrm{P}$ creat, collected/perfusate creatinine concentration ratio. Collection and perfusion rates are not significantly different (by paired $t$ test).

somes were frequently observed and most contained heterogeneous material including membranous structures, typical of autophagic vacuoles (Fig. 9). There also appeared to be an expansion of the Golgi apparatus (Figs. 8 and 9) and an increase in the number of ribosomes in the cytoplasm (Figs. 8-10). Cytoplasmic extensions were often observed protruding from the basal aspect of the principal cells and displacing the basement membrane (Fig. 10). These structures were typically associated with dense arrays of microfilaments. No differences were apparent in the amount of apical plasma membrane or in the height of the principal cells. No differences were observed when the intercalated cells from rats fed either diet were compared.

Scanning electron microscopy of initial IMCDs revealed that the apical surface morphology of the principal cells and the intercalated cells from rats fed either diet was consistent with previous descriptions of the cells in this segment $(26,27)$. The apical surface of principal cells typically displayed a moderate density of short microprojections and a single central cilium. The apical surface of intercalated cells was covered with complex microplicae. No differences in the morphology of the apical surface of either cell type were observed between the two groups.

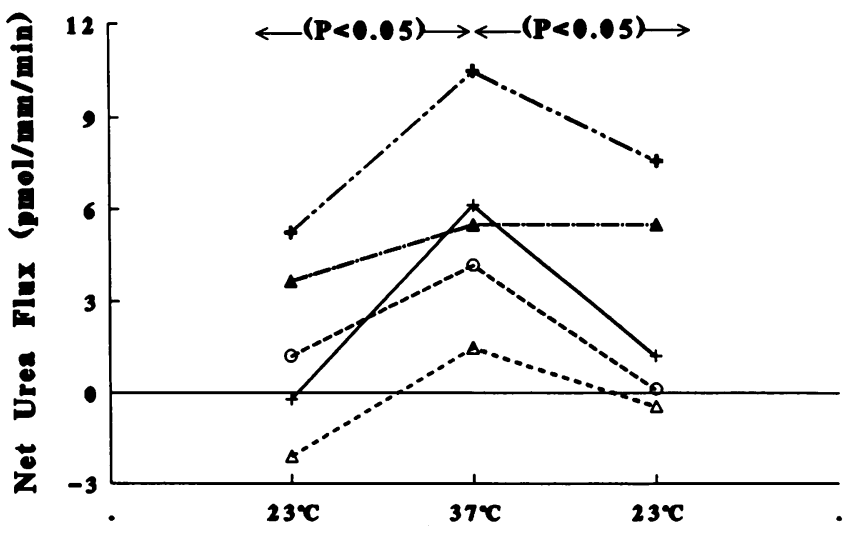

Figure 5. Initial IMCDs from rats fed $8 \%$ protein were perfused with identical perfusate and bath solutions. Lines connect data from individual tubules. Net urea flux was absent when the tubule was perfused at room temperature $\left(23^{\circ} \mathrm{C}\right)$. Significant net urea flux was present when the tubule was warmed to $37^{\circ} \mathrm{C}$, but disappeared when the tubule was cooled to $23^{\circ} \mathrm{C}$. 


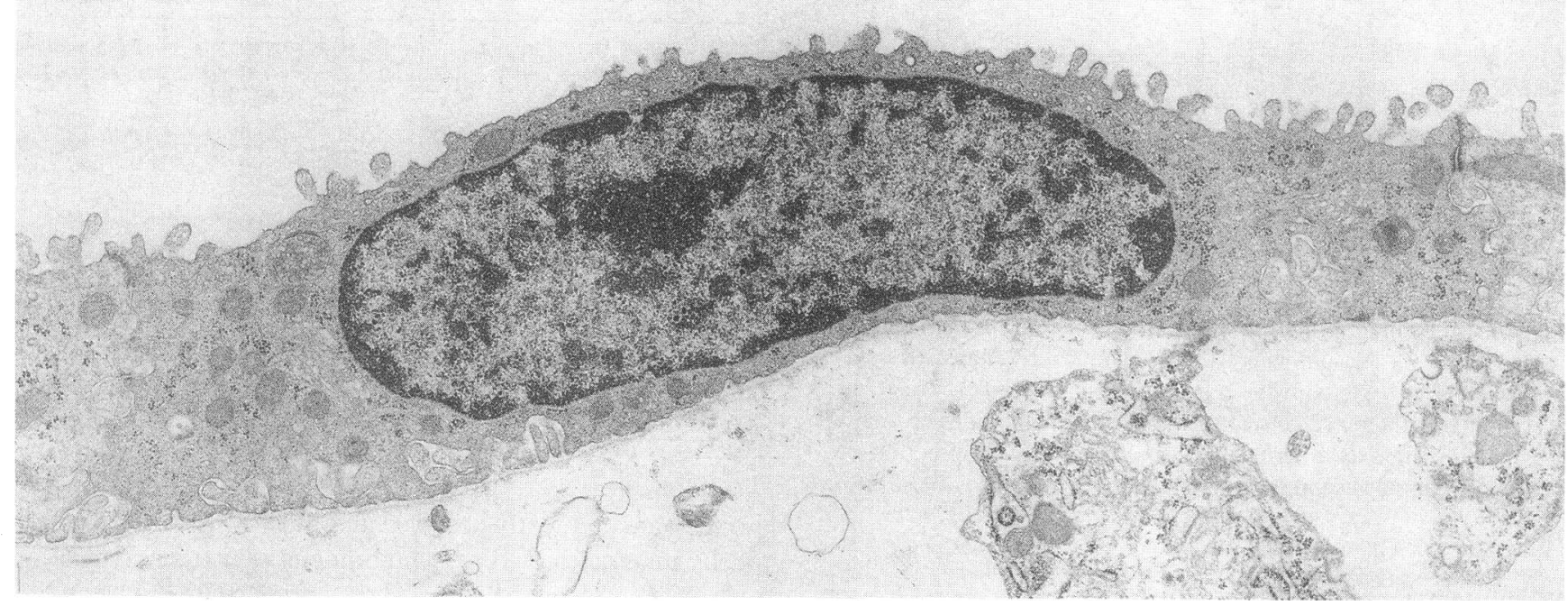

Figure 6. Transmission electron micrograph of a representative principal cell in the initial IMCD of a rat fed $18 \%$ dietary protein for 4 wk. The degree of complexity of the basolateral plasma membrane illustrated here is typical of the principal cells in the rats in this group. $\times 12,000$.

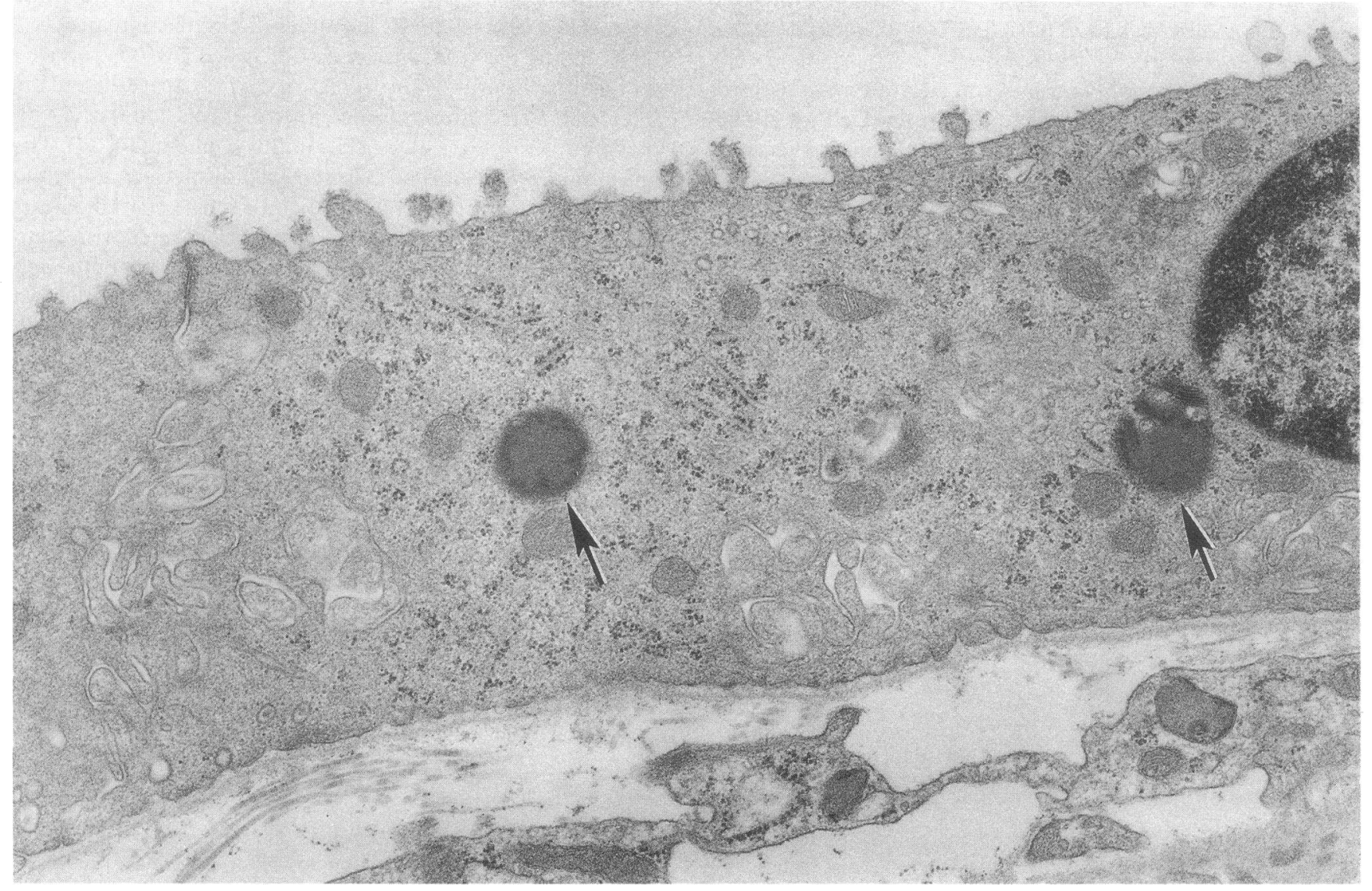

Figure 7. High magnification transmission electron micrograph of a principal cell in the initial IMCD of a rat fed $18 \%$ dietary protein. The degree of basolateral plasma membrane infoldings, the prevalence of ribosomes, and the lysosomal structures present (arrows) are typical of those observed in the control group. $\times 23,000$. 


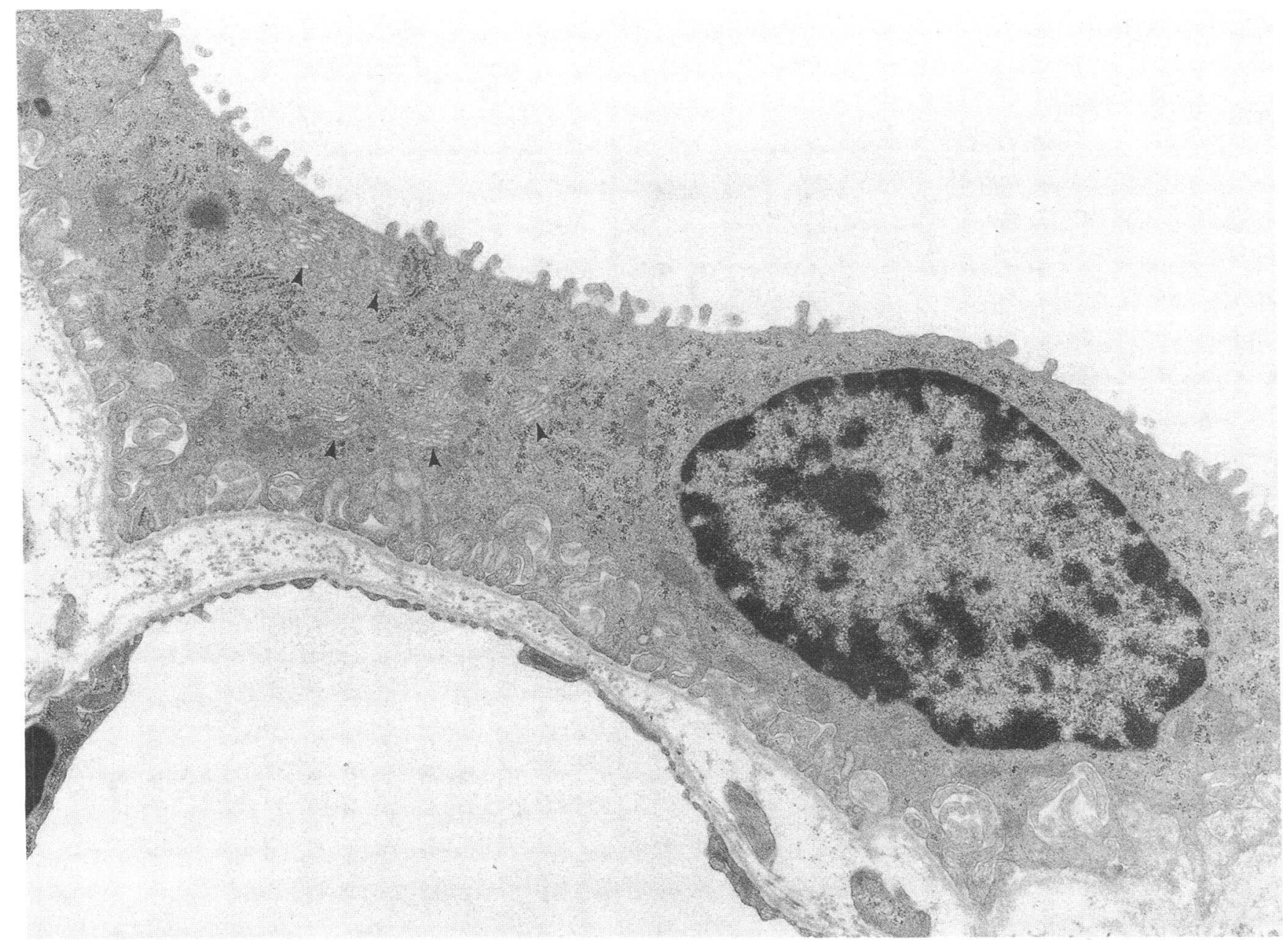

Figure 8. Transmission electron micrograph of a representative principal cell in the initial IMCD of a rat fed $8 \%$ dietary protein for 4 wk. The cell exhibits a marked increase in the basolateral plasma membrane infoldings, an extensive Golgi apparatus (arrowheads), and numerous ribosomes throughout the cytoplasm when compared to the principal cell illustrated in Fig. $6 . \times 12,000$.

Observation of the $\mathrm{IMCD}_{2}$ by transmission electron microscopy revealed that the ultrastructural features of this segment in rats fed either 18 or $8 \%$ protein were similar to those described in previous studies $(26,27)$. The majority of cells exhibited morphologic features typical of the IMCD cell (27) including numerous short microprojections over the apical surface, and a taller profile, a less complex basolateral plasma membrane, and wider lateral extracellular spaces than observed in principal cells, which represented a minority of cells in the $\mathrm{IMCD}_{2}$. Intercalated cells were rarely observed. Qualitative differences in the ultrastructure of the IMCD cells were not observed between the rats fed 18 and $8 \%$ dietary protein.

Morphometric analysis. The results of the morphometric analysis of the initial IMCD principal cells are summarized in Table III. Rats fed an $8 \%$ protein diet for 4 wk exhibited a statistically significant increase in both the surface density and boundary length per cell profile of the basolateral plasma membrane. No difference was detected in the mean cell profile area or in the surface density or boundary length per cell profile of the apical plasma membrane.

The results of the morphometric analysis of cells in the IMCD 2 are summarized in Table III. In rats fed an $8 \%$ protein diet for $4 \mathrm{wk}$, there was no significant change in mean cell profile area, or the surface density or boundary length per cell profile of either the apical or basolateral plasma membrane.

\section{Discussion}

We find that dietary protein restriction (8\% protein) for $4 \mathrm{wk}$ induces both active urea transport and vasopressin-stimulated passive urea permeability in initial IMCDs, concomitant with marked proliferation of the basolateral plasma membrane of principal cells in this segment. These data represent the first demonstration of active (net) urea transport in a mammalian collecting duct segment using tubule microperfusion. Our findings suggest that the reversal of the inner medullary urea gradient observed after prolonged protein restriction is due at least in part to the induction of these new urea transport processes in the initial IMCD. The dramatic structural changes observed in the principal cells of the initial IMCD after protein restriction suggests that the mechanism of the cellular response may involve the synthesis and insertion of urea transporters into the basolateral plasma membrane of these cells.

The $8 \%$ protein diet supplemented with methionine which we used in our study is the same as that used by Schmidt-Nielsen et al. $(1,5)$. We also find that rats on this diet grow, albeit 


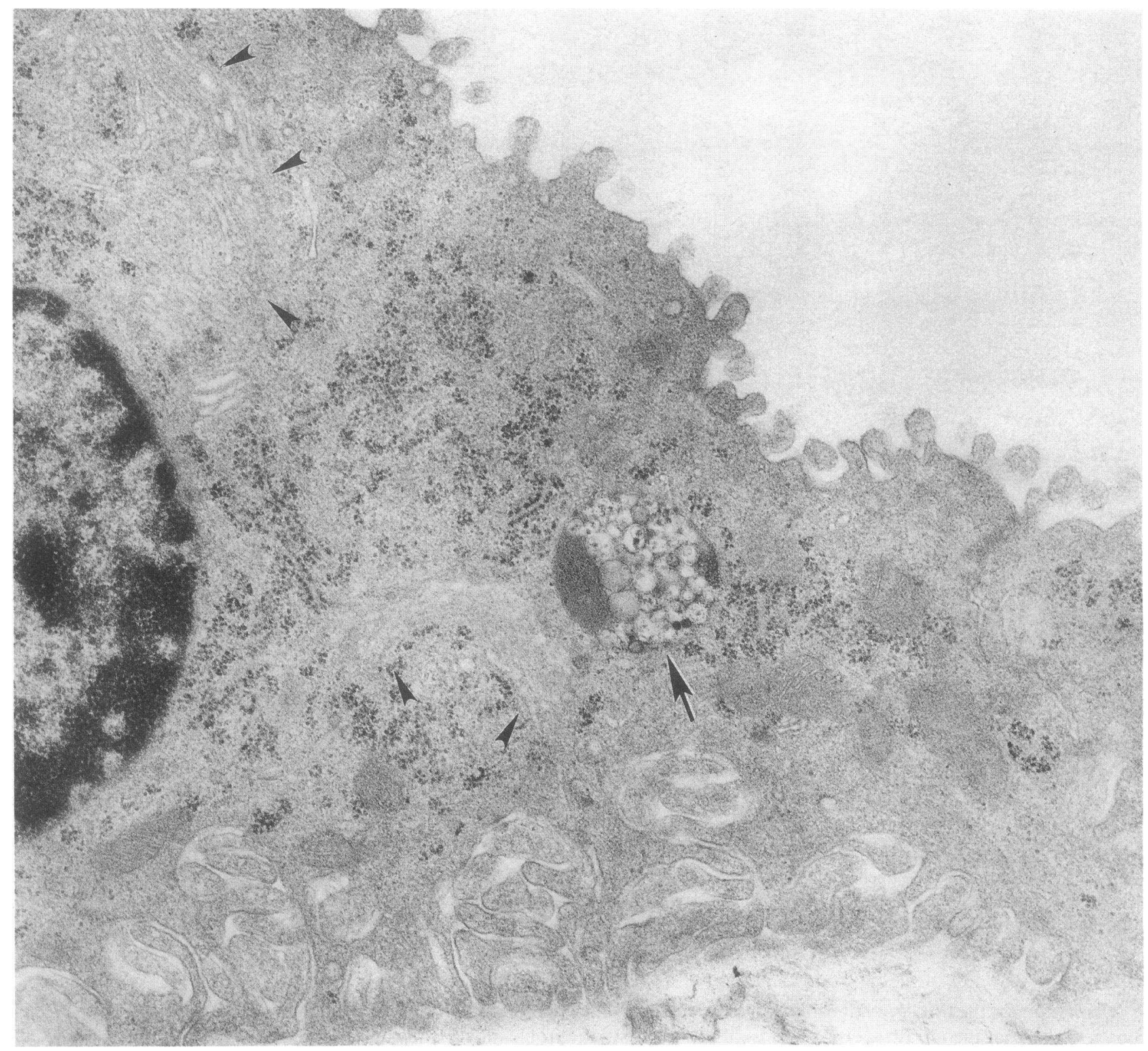

Figure 9. High magnification transmission electron micrograph of a principal cell in the initial IMCD of a rat fed $8 \%$ dietary protein. The cell contains an autophagic vacuole with heterogeneous contents (arrow) representative of those frequently observed in the low protein group. The cell also contains complex basolateral plasma membrane infoldings, an extensive Golgi apparatus (arrowheads), and numerous ribosomes. $\times 28,000$.

more slowly, than those on the $18 \%$ protein diet, and have normal values of serum creatinine and total protein $(34,35)$. We did observe a small $(0.4 \mathrm{~g} / \mathrm{dl})$ but statistically significant reduction in serum albumin in rats receiving $8 \%$ protein, but this value was still within the normal range $(34,35)$. The overall health of the rats, their growth, the normal values of total protein and albumin (albeit lower than in rats fed $18 \%$ protein) suggests that the rats we studied were not severely malnourished. Regardless, our results demonstrate fundamental changes in urea transport and cell structure in initial but not in terminal IMCDs after feeding rats $8 \%$ protein for 4 wk.

Passive urea transport. In rats fed the $18 \%$ protein diet, the basal passive urea permeability in initial IMCDs was similar to that in initial IMCDs from rats fed $8 \%$ protein. In contrast to rats fed $18 \%$ protein, vasopressin did stimulate urea permeability threefold in initial IMCDs from rats fed $8 \%$ protein for $4 \mathrm{wk}$. Phloretin inhibited this new, vasopressin-stimulated urea transport, as it does in terminal IMCDs from rats fed a standard diet (30-32). These results suggest that $8 \%$ protein feeding induces expression of facilitated urea transport in initial IMCDs to yield results which are qualitatively similar to properties found in terminal IMCDs.

Net urea transport. Active urea reabsorption across the IMCD has been inferred from micropuncture studies in rats on low protein diets $(4,6,7,9,11,23,24)$. A limitation of these studies is that the actual urea gradient across the micropuncturable IMCD cannot be measured in vivo. To demonstrate active urea transport, we perfused tubules with identical perfusate 


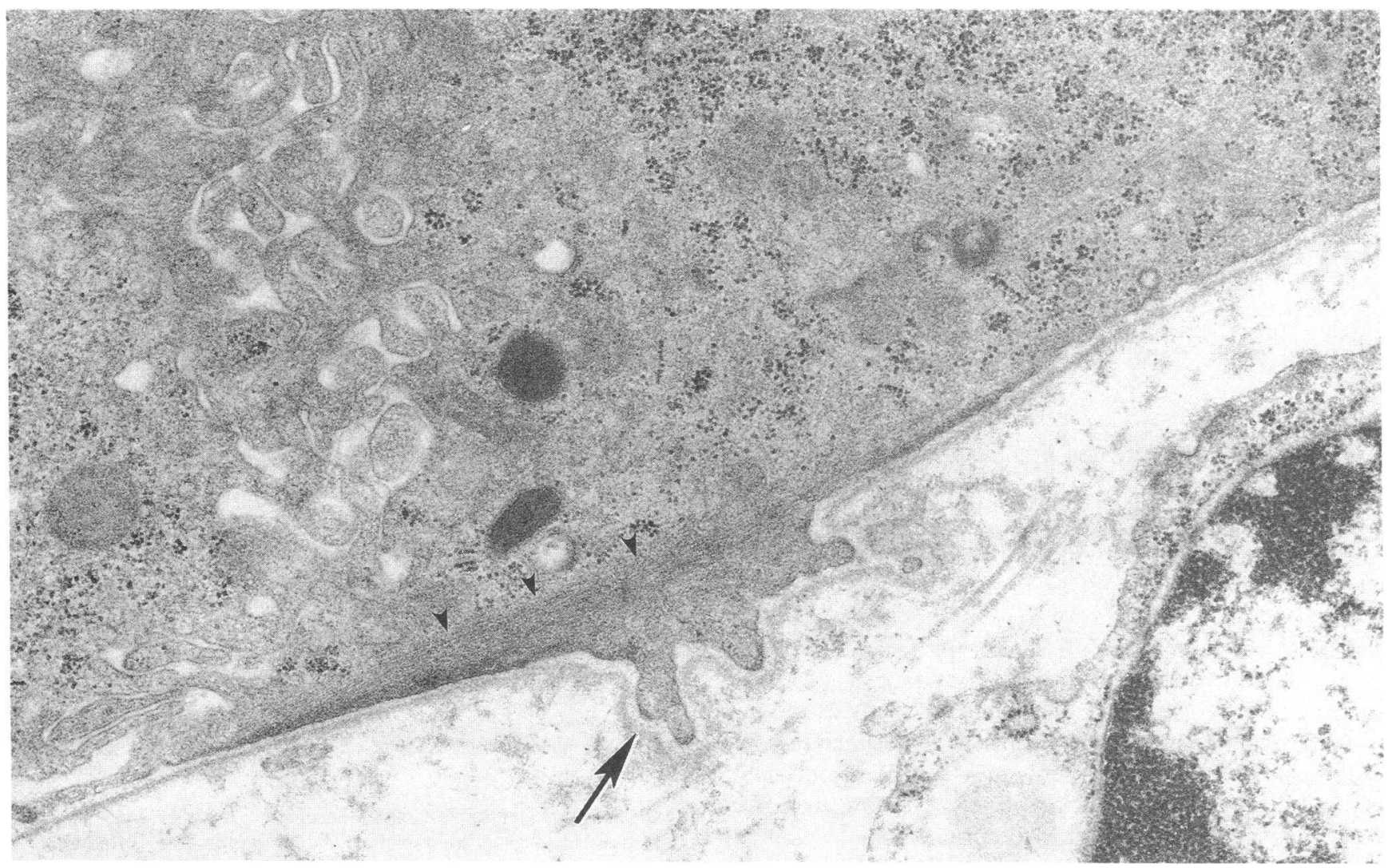

Figure 10. High magnification transmission electron micrograph of the basal region of a principal cell in the initial IMCD of a rat from the low protein group. There are complex infoldings of the lateral plasma membrane and numerous ribosomes. In addition, this cell exhibits the basal cytoplasmic processes (arrow) that were frequently observed in the low protein group. A dense array of microfilaments is adjacent to the basal process (arrowheads). $\times 27,000$.

and bath solutions, used a rapid bath flow rate, and measured urea concentration in the fluid exiting the bath. As the fluid exiting the bath had the same urea concentration as fluid entering the bath and the perfusate, we documented that the tubules were perfused with identical perfusate and bath.

A second limitation of the previous micropuncture studies is knowledge of which IMCD subsegment(s) were studied, since the most proximal portion of the surface IMCDs contain intercalated cells and resemble initial IMCDs morphologically (Verlander, J. W., unpublished observation). Thus, the micro- puncture studies may have included segments of IMCD that are morphologically, and possibly physiologically, similar to the initial IMCD. In the present study, we demonstrated active urea transport in initial IMCDs from rats fed $8 \%$ protein, but were unable to demonstrate active urea transport in terminal IMCDs, which correspond to the proximal portion of the terminal IMCD.

Effect of low protein diet in terminal IMCDs. In rats fed a standard protein diet, the terminal IMCD is the major site of urea reabsorption into the inner medulla $(21,25)$. Therefore,

Table III. Morphometric Analysis

\begin{tabular}{|c|c|c|c|c|c|c|}
\hline \multirow{2}{*}{$\begin{array}{l}\text { Dietary } \\
\text { protein }\end{array}$} & \multirow[b]{2}{*}{$\mathbf{N}$} & \multirow{2}{*}{$\begin{array}{l}\text { Cell profile } \\
\text { (area) }\end{array}$} & \multicolumn{2}{|c|}{ Surface density } & \multicolumn{2}{|c|}{ Boundary length } \\
\hline & & & Apical & Basolateral & Apical & Basolateral \\
\hline & & $\times 10^{-6} \mathrm{~mm}^{2}$ & \multicolumn{2}{|c|}{$\times 10^{-3} \mathrm{~mm}^{2} / \mathrm{mm}^{3}$} & \multicolumn{2}{|c|}{$\times 10^{-3} \mathrm{~mm} /$ cell profile } \\
\hline \multicolumn{7}{|c|}{ Initial IMCD principal cells } \\
\hline $18 \%$ & 4 & $31.48 \pm 3.00$ & $0.78 \pm 0.17$ & $2.21 \pm 0.18$ & $18.1 \pm 1.9$ & $54.7 \pm 7.9$ \\
\hline \multirow[t]{2}{*}{$8 \%$} & 5 & $34.92 \pm 1.36$ & $0.63 \pm 0.05$ & $3.11 \pm 0.05$ & $17.3 \pm 1.6$ & $85.2 \pm 2.6$ \\
\hline & & $P=\mathrm{NS}$ & $P=\mathrm{NS}$ & $P<0.02$ & $P=\mathrm{NS}$ & $P<0.04$ \\
\hline \multicolumn{7}{|c|}{ Terminal IMCD cells } \\
\hline $18 \%$ & 5 & $51.06 \pm 6.40$ & $0.54 \pm 0.10$ & $1.89 \pm 0.25$ & $20.2 \pm 2.8$ & $71.9 \pm 6.0$ \\
\hline \multirow[t]{2}{*}{$8 \%$} & 5 & $44.83 \pm 6.80$ & $0.62 \pm 0.12$ & $2.29 \pm 0.28$ & $19.8 \pm 2.8$ & $74.9 \pm 2.6$ \\
\hline & & $P=\mathrm{NS}$ & $P=\mathrm{NS}$ & $P=\mathrm{NS}$ & $P=\mathrm{NS}$ & $P=\mathrm{NS}$ \\
\hline
\end{tabular}

$\mathrm{N}$, number of rats. Data presented as mean \pm SE. $P$ values determined by unpaired $t$ test. 
we investigated whether adaptation to dietary protein restriction also involves changes in terminal IMCD urea transport. We found no difference between the 18 and $8 \%$ dietary protein groups in basal or vasopressin-stimulated passive urea permeability in the $\mathrm{IMCD}_{2}$. We also found no evidence for net urea transport in the $\mathrm{IMCD}_{2}$ from rats fed either diet.

We did not study tubules from the deepest third of the IMCD (20) for technical reasons. $\mathrm{IMCD}_{3}$ s are very short and difficult to dissect because of the branching pattern of IMCDs in the papillary tip. It has been suggested from tissue slice data that active urea transport may occur in this segment since the urinary urea concentration is less than the papillary tip tissue urea concentration $(2,3)$. However, the present study does not address urea transport mechanisms in the deepest third of the IMCD.

Morphological experiments. Reducing dietary protein from 18 to $8 \%$ for 4 wk changed the morphology of initial IMCD principal cells but had no detectable effect on cells in the $\mathrm{IMCD}_{2}$, the proximal portion of the terminal IMCD. The ultrastructural changes observed in the principal cells in the initial IMCD, which include expansion of the Golgi apparatus, an increase in the number of ribosomes, and a marked increase in the amount of basolateral plasma membrane, suggest that chronic dietary protein restriction stimulates synthesis and insertion of membrane components into the basolateral plasma membrane. Although the present study cannot identify any specific changes in plasma membrane composition, given the observation of two new urea transport processes in the isolated perfused tubule studies, we suggest that one or more urea transporters may be synthesized and inserted into the basolateral plasma membrane. The absence of changes in both morphology and urea transport in the $\mathrm{IMCD}_{2}$ further suggests that the increase in basolateral plasma membrane in the initial IMCD is related to enhanced urea transport.

Significance with respect to inner medullary urea handling. Both net urea reabsorption and vasopressin-stimulation of passive urea permeability in initial IMCDs could contribute to urea recycling at the base of the inner medulla. In addition, net urea reabsorption would increase the interstitial urea concentration regardless of whether vasopressin is present. If vasopressin were present, the increase in passive urea permeability would facilitate urea reabsorption. Any increase in urea reabsorption across the initial IMCD would decrease the urea concentration of fluid entering the terminal IMCD lumen, potentially decreasing the urea concentration within the deep inner medullary interstitium, hence contributing to the well-described reversal of the inner medullary urea concentration gradient in rats fed a low protein diet (1-3).

Role in concentrating mechanism. Adequate delivery of urea to the deep inner medulla is important to the concentrating mechanism $(36,37)$. In rats ingesting an $18 \%$ protein diet, urea reabsorption is delayed because of the low urea permeability of cortical collecting ducts, outer medullary collecting ducts, and initial IMCDs $(21,25,38)$. Vasopressin (21) and hypertonic $\mathrm{NaCl}(32,39)$ stimulate rapid passive urea reabsorption from the terminal IMCD by a facilitated urea transport process driven by the large lumen-to-bath urea concentration gradient. Mathematical simulations of the concentrating mechanism suggest that increased urea reabsorption across the initial IMCD would decrease maximal concentrating ability by decreasing delivery of urea to the deep inner medullary interstitium $(40,41)$. Thus, increased urea reabsorption across the initial IMCD may contribute to the well-known decrease in urine concentrating ability observed in man and animals fed low protein diets $(42-45)$.

\section{Acknowledgments}

The authors thank Drs. William E. Mitch and C. Craig Tisher for their helpful discussions during the experimental studies and their critical reading of this manuscript. The authors also thank Dr. C. Craig Tisher for reviewing the electron microscopy photomicrographs, and Ms. Ann Boles for performing the aldosterone radioimmunoassays.

This work was supported by National Institutes of Health grants R29-DK41707 and R01-DK45688. T. Isozaki performed portions of this work during the tenure of a research fellowship from the National Kidney Foundation. J. M. Sands performed this work during the tenure of an Established Investigatorship from the American Heart Association.

\section{References}

1. Schmidt-Nielsen, B., J. M. Barrett, B. Graves, and B. Crossley. 1985. Physiological and morphological responses of the rat kidney to reduced dietary protein. Am. J. Physiol. 248:F31-F42.

2. Truniger, B., and B. Schmidt-Nielsen. 1964. Intrarenal distribution of urea and related compounds: effect of nitrogen intake. Am. J. Physiol. 207:971-978.

3. Truniger, B., and B. Schmidt-Nielsen. 1970. Intrarenal distribution and transtubular movement of urea and related compounds. In Urea and the Kidney. B. Schmidt-Nielsen and D. W. S. Kerr, editors. Excerpta Medica, Amsterdam, Netherlands, pp. 314-322.

4. Ullrich, K. J., G. Rumrich, and B. Schmidt-Nielsen. 1967. Urea transport in the collecting duct of rats on normal and low protein diet. Pfluegers Arch. 295:147-156.

5. Peil, A. E., H. Stolte, and B. Schmidt-Nielsen. 1990. Uncoupling of glomerular and tubular regulations of urea excretion in rat. Am. J. Physiol. 258:F1666F1674.

6. Danielson, R. A., and B. Schmidt-Nielsen. 1972. Recirculation of urea analogs from renal collecting ducts of high- and low-protein-fed rats. Am. J. Physiol. 223:130-137.

7. Danielson, R. A., B. Schmidt-Nielsen, and C. Hohberger. 1970. Micropuncture study of the regulation of urea excretion by the collecting ducts in rats on high and low protein diets. In Urea and the Kidney. B. Schmidt-Nielsen and

D. W. S. Kerr, editors. Excerpta Medica, Amsterdam, Netherlands, pp. 375-384. 8. Wilson, D. R., and H. Sonnenberg. 1982. Urea reabsorption in the medullary collecting duct of protein-depleted young rats before and after urea infusion. Pfluegers Arch. 393:302-309.

9. Clapp, J. R. 1966. Renal tubular reabsorption of urea in normal and protein-depleted rats. Am. J. Physiol. 210:1304-1308.

10. Joppich, R., and P. Deetjen. 1971. The relationship between the reabsorption of urea and of water in the distal tubule of the rat kidney. Pfluegers Arch. 329:172-185.

11. Lassiter, W. E., C. W. Gottschalk, and M. Mylle. 1961. Micropuncture study of net transtubular movement of water and urea in nondiuretic mammalian kidney. Am. J. Physiol. 200:1139-1146.

12. Knepper, M. A., R. A. Danielson, G. M. Saidel, and K. H. Johnston. 1975. Effects of dietary protein restriction and glucocorticoid administration on urea excretion in rats. Kidney Int. 8:303-315.

13. Rabinowitz, L., R. A. Gunther, E. S. Shoji, R. A. Freedland, and E. H. Avery. 1973. Effects of high and low protein diets on sheep renal function and metabolism. Kidney Int. 4:188-207.

14. Schmidt-Nielsen, B., and R. O'Dell. 1959. Effect of diet on distribution of urea and electrolytes in kidneys of sheep. Am. J. Physiol. 197:856-860.

15. Leng, L., M. Szanyiova, and K. Boda. 1985. The renal response of sheep to a low dietary nitrogen intake. Physiol. Bohemoslov. 34:147-154.

16. Scott, D., and G. D. Mason. 1970. Renal tubular reabsorption of urea in sheep. Q. J. Exp. Physiol. 55:275-283.

17. Schmidt-Nielsen, B., H. Osaki, H. V. Murdaugh, Jr., and R. O'Dell. 1958. Renal regulation of urea excretion in sheep. Am. J. Physiol. 194:221-228.

18. Schmidt-Nielsen, B., K. Schmidt-Nielsen, T. R. Houpt, and S. A. Jarnum. 1957. Urea excretion in the camel. Am. J. Physiol. 188:477-484.

19. Murdaugh, H. V., B. Schmidt-Nielsen, E. M. Doyle, and R. O'Dell. 1958. Renal tubular regulation of urea excretion in man. J. Appl. Physiol. 13:263-268.

20. Madsen, K. M., and C. C. Tisher. 1986. Structural-functional relationship along the distal nephron. Am. J. Physiol. 250:F1-F15.

21. Sands, J. M., H. Nonoguchi, and M. A. Knepper. 1987. Vasopressin effects on urea and $\mathrm{H}_{2} \mathrm{O}$ transport in inner medullary collecting duct subsegments. Am. J. Physiol. 253:F823-F832. 
22. Bray, G. A., and A. S. Preston. 1961. Effect of urea on urine concentration in the rat. J. Clin. Invest. 40:1952-1960.

23. Lassiter, W. E., M. Mylle, and C. W. Gottschalk. 1966. Micropuncture study of urea transport in rat renal medulla. Am. J. Physiol. 210:965-970.

24. Wilson, D. R., and H. Sonnenberg. 1981. Urea secretion in medullary collecting duct of the rat kidney during water and mannitol diuresis. Am. J. Physiol. 240:F165-F171.

25. Sands, J. M., and M. A. Knepper. 1987. Urea premeability of mammalian inner medullary collecting duct system and papillary surface epithelium. J. Clin. Invest. 79:138-147.

26. Clapp, W. L., K. M. Madsen, J. W. Verlander, and C. C. Tisher. 1987. Intercalated cells of the rat inner medullary collecting duct. Kidney Int. 31:1080 1087.

27. Clapp, W. L., K. M. Madsen, J. W. Verlander, and C. C. Tisher 1989. Morphologic heterogeneity along the rat inner medullary collecting duct. $L a b$. Invest. 60:219-230.

28. Nonoguchi, H., J. M. Sands, and M. A. Knepper. 1988. Atrial natriuretic factor inhibits vasopressin-stimulated osmotic water permeability in rat inner medullary collecting duct. J. Clin. Invest. 82:1383-1390.

29. Knepper, M. A., D. W. Good, and M. B. Burg. 1985. Ammonia and bicarbonate transport by rat cortical collecting ducts perfused in vitro. Am. J. Physiol. 249:F870-F877.

30. Chou, C.-L., and M. A. Knepper. 1989. Inhibition of urea transport in inner medullary collecting duct by phloretin and urea analogues. Am. J. Physiol. 257:F359-F365.

31. Kondo, Y., and M. Imai. 1987. Effects of glutaraldehyde fixation on renal tubular function. I. Preservation of vasopressin-stimulated water and urea pathways in rat papillary collecting duct. Pfluegers Arch. 408:479-483.

32. Gillin, A. G., and J. M. Sands. 1992. Characteristics of osmolarity-stimulated urea transport in the rat IMCD. Am. J. Physiol. 262:F1061-F1067.

33. Snedecor, G. W., and W. G. Cochran. 1980. Statistical Methods. Iowa State University Press, Ames, IA.
34. Fiorotto, M. L., H.-P. Sheng, H. J. Evans, A. D. Leblanc, P. C. Johnson, and B. L. Nichols. 1987. Specific effects of weight loss, protein deficiency, and energy deprivation on the water and electrolyte composition of young rats. $J$. Nutr. 117:933-940.

35. Feehally, J., F. Baker, and J. Walls. 1988. Dietary protein manipulation in experimental nephrotic syndrome. Nephron. 50:247-252.

36. Kokko, J. P., and F. C. Rector. 1972. Countercurrent multiplication system without active transport in inner medulla. Kidney Int. 2:214-223.

37. Stephenson, J. L. 1972. Concentration of urine in a central core model of the renal counterflow system. Kidney Int. 2:85-94.

38. Knepper, M. A. 1983. Urea transport in isolated thick ascending limbs and collecting ducts from rats. Am. J. Physiol. 245:F634-F639.

39. Sands, J. M., and D. C. Schrader. 1991. An independent effect of osmolality on urea transport in rat terminal IMCDs. J. Clin. Invest. 88:137-142.

40. Chandhoke, P. S., and G. M. Saidel. 1981. Mathematical model of mass transport throughout the kidney. Effects of nephron heterogeneity and tubularvascular organization. Ann. Biomed. Eng. 9:263-301.

41. Wexler, A. S., R. E. Kalaba, and D. J. Marsh. 1991. Three-dimensional anatomy and renal concentrating mechanism. I. Modelling results. Am. J. Physiol. 260:F368-F383.

42. Gamble, J. L., C. F. McKhann, A. M. Butler, and E. Tuthill. 1934. An economy of water in renal function referable to urea. Am. J. Physiol. 109:139154.

43. Pennell, J. P., V. Sanjana, N. R. Frey, and R. L. Jamison. 1975. The effect of urea infusion on the urinary concentrating mechanism in protein-depleted rats. J. Clin. Invest. 55:399-409.

44. Crawford, J. D., A. P. Doyle, and H. Probst. 1959. Service of urea in renal water conservation. Am. J. Physiol. 196:545-548.

45. Levinsky, N. G., and R. W. Berliner. 1959. The role of urea in the urine concentrating mechanism. J. Clin. Invest. 38:741-748. 